University of Montana

ScholarWorks at University of Montana

Fall 9-1-2005

\title{
FOR 303.01: Introduction to Geographic Information Systems
}

Woodam Chung

University of Montana - Missoula, woodam.chung@umontana.edu

Follow this and additional works at: https://scholarworks.umt.edu/syllabi

Let us know how access to this document benefits you.

\section{Recommended Citation}

Chung, Woodam, "FOR 303.01: Introduction to Geographic Information Systems" (2005). University of Montana Course Syllabi. 9789.

https://scholarworks.umt.edu/syllabi/9789

This Syllabus is brought to you for free and open access by the Open Educational Resources (OER) at ScholarWorks at University of Montana. It has been accepted for inclusion in University of Montana Course Syllabi by an authorized administrator of ScholarWorks at University of Montana. For more information, please contact scholarworks@mso.umt.edu. 


\title{
FOR303 Introduction to Geographic Information Systems
}

\author{
Fall 2005
}

\author{
Instructor: \\ Office: \\ Phone: \\ Email: \\ Office Hours: \\ Woodam Chung \\ FOR 207B \\ (406) 243-6606 \\ woodam.chung@umontana.edu \\ MW 10:00A - 12:00P, TR 11:00A - 12:00P \\ Teaching Assistant: \\ Office: \\ Agus Suratno \\ SC442 \\ Phone: \\ (406) 243-6116 \\ Email: \\ go_griezzly@yahoo.com \\ Class Times: \\ Two 1-hour lectures (FOR301) : \\ TR 8:10A - 9:00A \\ One 2-hour lab (JOUR106) : : T 9:10A - 11:00A (section 2) \\ R 9:10A - 11:00A (section 3) \\ Optional Text: \\ - Clarke, K. C. 2002. "Getting Started with Geographic Information Systems", \\ $4^{\text {th }}$ ed. Prentice-Hall \\ - Tim Ormsby, Eileen Napoleon, Robert Burke, Laura Feaster, and Carolyn \\ Groessl. 2004. "Getting to know ArcGIS Desktop", Second Edition. ESRI \\ Press \\ Other references: \\ - $\quad$ Burrough, P.A. and Rachael A. McDonell. 1998. Principles of Geographic \\ Information Systems. Oxford University Press. \\ - Aronoff, Stan. 1989. Geographic Information Systems: A Management \\ Perspective. WDL Publications. \\ - Bonham-Carter, G. F. 1994. Geographic Information Systems for \\ Geoscientists. Pergamon. \\ - $\quad$ Robinson, A.H. et al. 1995. Elements of Cartography. John Wiley \& Sons.
}

\section{Course Descriptions:}

The purpose of this course is to help students understand the basic GIS concepts and techniques. Class activities will examine technical concepts of ground coordinates and maps, data structures, the integration of map data and tables of descriptive information linked to maps, and analytical use of spatial information. The laboratory components of this course will provide the students with a basic working knowledge of the ArcGIS software package.

2. Course Learning Objectives:

- Understand the basic terminology, structures, concepts, and theories of GIS

- Gain a basic skill to perform spatial analyses using spatial and attribute data within a GIS environment.

- Investigate in-depth GIS processes that are of interest to you.

3. Course Policies:

- All assignments are due at the BEGINNING of lab.

- Late assignments will be penalized $10 \%$ per day.

- All work must be neat, legible and complete.

- All figures, drawings, and tables should be titled. 
- Work that does not confirm to the above requirements and the designated format may not be accepted.

- There will be no make-up exams.

- Any requests for deviations in the course policies, schedule, or deadlines must be made in writing to the instructor. These requests should be made in the form of a business letter that clearly states and defends your request. Email is acceptable but should be confirmed as having been received.

4. Grading:

- First Exam 25\%

- Second Exam 25\%

- Final Project $30 \%$

- Lab Exercises $20 \%$

$100 \%$

- Letter grades will be based on the following. Depending upon class performance, the curve may be shifted downward but not upward.

\begin{tabular}{|c|c|c|c|}
\hline A & $93 \%-100 \%$ & C & $73 \%-77 \%$ \\
\hline A- & $90 \%-93 \%$ & C- & $70 \%-73 \%$ \\
\hline B+ & $87 \%-90 \%$ & D+ & $67 \%-70 \%$ \\
\hline B & $83 \%-87 \%$ & D & $63 \%-67 \%$ \\
\hline B- & $80 \%-83 \%$ & D- & $60 \%-63 \%$ \\
\hline C+ & $77 \%-80 \%$ & F & $0 \%-60 \%$ \\
\hline
\end{tabular}

5. Tentative Course Schedule:

\begin{tabular}{|c|l|l|l|}
\hline Week & Date & \multicolumn{1}{|c|}{ Lecture Topic } & $\begin{array}{c}\text { Readings } \\
\text { (Clarke K.C.) }\end{array}$ \\
\hline 1 & Aug. 30 & Welcome to GIS & \\
\hline & Sep. 1 & What is a GIS & Chap. 1 \\
\hline 2 & Sep. 6 & History of GIS & Chap. 1 \\
\hline & Sep. 8 & Cartographic Fundamentals I. (in General) & Chap. 2 \\
\hline 3 & Sep. 13 & $\begin{array}{l}\text { Cartographic Fundamentals II. (Map scale and } \\
\text { projection) }\end{array}$ & Chap. 2 \\
\hline & Sep. 15 & Cartographic Fundamentals III. (Coordinate systems) & Chap. 2 \\
\hline 4 & Sep. 20 & Data Representation I. (Map as numbers) & Chap. 3 \\
\hline & Sep. 22 & Data Representation II. (Raster data structure) & Chap. 3 \\
\hline 5 & Sep. 27 & Data Representation II. (Raster data structure) & Chap. 3 \\
\hline & Sep. 29 & Data Representation III. (Vector data structure) & Chap. 3 \\
\hline 6 & Oct. 4 & Data Representation III. (Vector data structure) & Chap. 3 \\
\hline & Oct. 6 & Reviews for Midterm & \\
\hline 7 & Oct. 11 & Midterm Examination I. & \\
\hline & Oct. 13 & Final Project Descriptions & \\
\hline 8 & Oct. 18 & Data Representation IV. (TIN and data format) & \\
\hline & Oct. 20 & Data Representation V. (Future data models) & Chap. 4 \\
\hline 9 & Oct. 25 & Data Management I. (Data input) & Chap. 4 \\
\hline & Oct. 27 & Data Management II. (Data editing) & \\
\hline 10 & Nov. 1 & Data Management II. (Data editing) & \\
\hline & Nov. 3 & Data Management III. (DBMS) & \\
\hline 11 & Nov. 8 & Data Management III. (DBMS and metadata) & \\
\hline & & & \\
\hline
\end{tabular}




\begin{tabular}{|c|l|l|l|}
\hline & Nov. 10 & Spatial Analysis Functions I. (Spatial queries) & Chap. 5 \\
\hline 12 & Nov. 15 & Spatial Analysis Functions I. (Spatial queries) & Chap. 5 \\
\hline & Nov. 17 & Spatial Analysis Functions II. (Other analytical functions) & Chap. 6 \\
\hline 13 & Nov. 22 & Data Accuracy & \\
\hline & Nov. 24 & Thanksgiving vacation!!! & \\
\hline 14 & Nov. 29 & GIS Outputs \& Reviews for Midterm & Chap. 7 \\
\hline & Dec. 1 & Midterm Examination II. & \\
\hline 15 & Dec. 6 & Project Presentations & \\
\hline & Dec. 8 & Project Presentations & \\
\hline 16 & Dec. 14 & Final week - Project due by 6:00PM & \\
\hline
\end{tabular}

6. Tentative Lab Schedule:

\begin{tabular}{|c|c|c|}
\hline Week & Dates & Lab Topic \\
\hline 1 & Aug. 30 \& Sep. 1 & No labs this week \\
\hline 2 & Sep. $6 \& 8$ & Lab \#1. GIS and WWW \\
\hline 3 & Sep. $13 \& 15$ & Lab \#2. Map Fundamentals \\
\hline 4 & Sep. $20 \& 22$ & Lab \#3. Introduction to ArcGIS \\
\hline 5 & Sep. $27 \& 29$ & Lab \#3. Introduction to ArcGIS (continued) \\
\hline 6 & Oct. 4 \& 6 & Lab \#4. Manipulating Theme Tables in ArcGIS \\
\hline 7 & Oct. $11 \& 13$ & Lab \#5. GPS Field Exercise \\
\hline 8 & Oct. $18 \& 20$ & Lab \#6. Reprojecting coordinate data \\
\hline 9 & Oct. $25 \& 27$ & Lab \#7. Terrain Analysis with Raster Data \\
\hline 10 & Nov. $1 \& 3$ & Lab \#8. Manipulating Theme Polygon Attributes in ArcGIS \\
\hline 11 & Nov. $8 \& 10$ & Lab \#9. Spatial Analysis with Lubrecht Forest Data \\
\hline 12 & Nov. $15 \& 17$ & Lab \#9. Spatial Analysis with Lubrecht Forest Data (continued) \\
\hline 13 & Nov. $22 \& 24$ & Thanksgiving - No labs \\
\hline 14 & Nov. 29 \& Dec. 1 & Working on group projects \\
\hline 15 & Dec. $6 \& 8$ & Lab \#10. Site-Suitability Analysis \\
\hline 16 & Dec. $13 \& 15$ & Final week - No labs \\
\hline
\end{tabular}

